Article

\title{
Financing Sustainable Small-Scale Forestry: Lessons from Developing National Forest Financing Strategies in Latin America
}

\author{
Marco Boscolo ${ }^{1} *$, Kees van Dijk ${ }^{2}$ and Herman Savenije ${ }^{2}$ \\ 1 FAO, Forestry Department, viale delle Terme di Caracalla, Rome, 00153, Italy \\ 2 Tropenbos International, Lawickse Allee 11, 6701 AN Wageningen, The Netherlands; \\ E-Mails: kees.vandijk@ tropenbos.org (K.v.D.); herman.savenije @ tropenbos.org (H.S.) \\ * Author to whom correspondence should be addressed; E-Mail: marco.boscolo@ fao.org; \\ Tel.: +39-06-5705-4424; Fax: +39-06-5705-5514.
}

Received: 27 October 2010; in revised form: 17 November 2010 / Accepted: 17 November 2010 / Published: 6 December 2010

\begin{abstract}
The problems that hamper the financing of sustainable forest management (SFM) are manifold and complex. However, forestry is also facing unprecedented opportunities. The multiple functions and values of forests are increasingly recognized as part of the solution to pressing global issues (e.g., climate change, energy scarcity, poverty, environmental degradation, biodiversity loss and raw material supply). Emerging initiatives to enhance forest carbon stocks and cut greenhouse gas emissions associated with forest clearing (known as REDD+), together with voluntary carbon markets, are offering additional funding options for SFM. Indigenous peoples, local communities and small scale farmers feature as key players in the discourse on implementing such initiatives. Based on the experience of countries developing national forest financing strategies and instruments, we suggest the following points be considered when financing such initiatives, particularly for small scale forestry: (1) Integrate financing of REDD+ and similar initiatives within broader national strategies for SFM financing; (2) Design REDD+ finance mechanisms that are 'community ready', i.e., tailored to local realities; (3) Consider existing livelihood strategies as the starting point; (4) Build on existing structures, but be mindful of their strengths and weaknesses; (5) Be strategic with your priority actions; and (6) Promote innovation, knowledge sharing and information exchange.
\end{abstract}

Keywords: forest financing; REDD+; small scale forestry; Latin America 


\section{Introduction}

In recent years, the question of how to broaden and diversify the financial basis for sustainable forest management (SFM) has received increasing attention in policy, research and development fora. One of the main challenges countries face in reducing forest degradation and deforestation - and in enhancing the contribution of forests to development - is how to increase the competitiveness and attractiveness of SFM compared with other land uses. Achieving this requires additional financing for inputs, as well as increased revenues from the provision of forest goods and services. If forest users do not derive a sufficiently high return from SFM, in comparison with unsustainable uses or land conversion, deforestation and forest degradation are clearly the rational outcomes to expect.

Financing is needed to solve cash flow problems where costs are incurred before revenues are earned. The time gap between costs and revenues can be several years, as in the case of establishing plantations and natural forest rehabilitation; several months, as in the case of developing a nature-based business; or less, as in the case of financing operating capital or labor. Financing is also needed to adopt efficient technologies (e.g., machinery, know-how, business plans) or to perform a catalytic or demonstration role. Adoption of new technologies can help reduce product waste and environmental impact whilst increasing profitability. Financing is needed to manage risks (e.g., through guarantees, risk-sharing arrangements, etc.), thereby containing the impact of uncertainties such as market fluctuations or fires, and to improve, maintain and adapt, the overall policy and institutional environment (e.g., participatory policy and legislative processes, technology acquisition, information management, communication, law enforcement, processes and procedures, research, extension, other core institutional functions). Regardless of the time gap between costs and revenues, lack of affordable or accessible financing options prevents the implementation of economically attractive forest management activities.

Equally important is finding ways to increase SFM's ability to finance itself, such as through the sale (adequate compensation) of the multiple products and services it generates. In other words, it is essential to look also at enhancing the economic benefits that users derive from sustainable forestry.

\subsection{The Challenges and Opportunities}

The problems that hamper the financing of SFM are manifold and complex. Such problems include: undervaluation of the multifunctionality of forests; strong dependence and focus on timber as the main source of income; inequity in the division of costs and benefits in the wood chain; the long-term nature of forestry cycles; and the low profitability and high (perceived) risks of forestry investments [1,2]. Furthermore, forest practices in the tropics often exhibit low productivity and efficiency because they are carried out with outdated technologies and without sustainability considerations. Perhaps even more importantly, insecure tenure, weak institutions, poor sector governance and adverse policies contribute to making investments and business development in sustainable forestry unattractive.

However, forestry is also facing unprecedented opportunities. The multiple functions and values of forests are increasingly recognized as part of the solution to pressing global issues (e.g., climate change, energy scarcity, poverty, environmental degradation, biodiversity loss and raw material supply); this is also reflected in the wide range of international fora in which forests are being discussed, prominently: 
UNFCCC, UNCCD, UNCBD, UNFF, ITTO, WTO, CITES, IUCN, FSC. Partly as a response to this growing recognition, an array of new and promising financing sources, instruments and mechanisms is emerging at global and country levels, especially to address climate change, promote bioenergy, protect ecosystems through payments for environmental services (PES) and tap into capital market instruments. All these opportunities, if realized, can contribute to creating additional and diversified sources of investment and income for forests and enhancing livelihoods of forest-dependent people.

\subsection{REDD+ and Forest People}

Emerging initiatives to enhance forest carbon stocks and cut greenhouse gas emissions associated with forest clearing (known as REDD+), together with voluntary carbon markets are offering additional funding options for SFM. For example, the last couple of years have witnessed the operationalization of the Forest Carbon Partnership Facility, the UN-REDD program, and the Forest Investment Program. Thus far, analyses on REDD+ have heavily emphasized international- and national-level design issues. They indicate that a future REDD+ agreement will likely be broad, and will probably include general provisions on scope, implementation, monitoring and verification, incentives and other types of support [3]. The details, including the identification and application of best policies and practices, will largely be left to the countries/parties, provided they comply with the general conditions. The final success of REDD+ will largely depend on how it is integrated into each country's policies and how it is practically shaped at ground level. The national design issues, including the process through which finance is received and distributed across stakeholders at national, subnational and local levels, will be a significant determinant of whether REDD+ funds can be used effectively and reach all relevant beneficiaries, including those most in need (e.g., [4]).

Indigenous peoples, local communities and small scale farmers feature as key players in the discourse on implementing REDD+. A variety of motives underpin the need for their active involvement: that forest-dependent people own or use large tracts of forestland; that in many places they are important agents of degradation and, therefore, must be part of the solution; and that REDD+ must address such issues as poverty alleviation, equity and justice. There is a broad understanding that the REDD+ finance design must include specific safeguards to ensure that the mechanism represents not a threat or risk but an opportunity to benefit poor, marginalized and vulnerable groups.

\subsection{Scope and Limitations of the Paper}

This paper contributes to these explorations by reviewing the issues we have encountered in supporting efforts to finance SFM, in particular when carried out by local communities, indigenous groups and small forest owners and users in selected Latin American countries. In particular, we reflect on the findings from a regional knowledge-sharing initiative, which was carried out between 2005 and 2007, by Food and Agriculture Organization (FAO) and the National Forest Programme (NFP) Facility, in partnership with IUCN-ORMA, CCAD (Central American Commission for Environment and Development), OTCA/DGIS/GTZ-BMZ, and with support from the Ministry of Agriculture, Nature and Food Quality of the Netherlands and the German Government. It focused initially on Latin America for the leadership role it has played in past decades in the experimentation with innovative financing mechanisms for SFM. The initiative produced 19 country assessments, subregional and 
regional syntheses and numerous workshops. An overall synthesis was prepared by van Dijk and Savenije [1], whose main findings are summarized in [5,6]. The countries included in the national studies were: Argentina, Belize, Bolivia, Brazil, Chile, Colombia, Costa Rica, Dominican Rep., Ecuador, El Salvador, Guatemala, Honduras, Mexico, Nicaragua, Panama, Paraguay, Peru, Uruguay and Venezuela.

The paper also builds on the lessons that are emerging from FAO and its partners' ongoing work in support of national forest financing strategies in Guatemala, Paraguay, El Salvador and Ecuador (see [7]). Relevant lessons are then linked to the opportunities and challenges that arise from forest (carbon) financing (e.g., REDD+). The paper concludes with some aspects that should be considered by donors and development agencies when supporting the development of forest financing instruments and strategies and which may be relevant to REDD+ financing at the national level.

Key issues addressed in the paper include:

- How do small forest/land users, local communities and indigenous groups finance their forest activities? What are their financing sources and modalities, and what constraints do they face in accessing finance?

- What are the challenges and opportunities in enhancing financing for SFM for these groups?

- What considerations merit attention for linking local financing realities with forest carbon financing (e.g., REDD+) and other payments for environmental services (PES) schemes to enhance SFM?

As mentioned in the introduction, financing SFM includes addressing investment needs to solve cash flow problems or to perform a catalytic or demonstration role. It also includes creating and enhancing policies and markets for forest products and services that currently have no or limited value. In this paper, the emphasis is on the challenge to address investment needs.

\section{Financing Small-Scale Forestry: Realities and Issues}

This section summarizes a selected number of observations that have emerged from the initiatives mentioned in the previous section. Complementing these observations is additional information on communities' financing realities based on the authors' experience.

\subsection{Local Diversity, Specificity and the Need to Differentiate: 'One Size Does Not Fit All'}

The assessment of forest finance in Latin America [1] emphasizes the large diversity of situations that exist both between and within countries and forest stakeholder groups. Behind generic terms such as 'local forest communities' or 'forest-dependent people' lie profound differences in terms of contexts, features, interests and dynamics (see Box 1). Such differences are reflected in different cultural and social values, ecological and tenurial settings, relationship to forests, motivations, readiness to embrace change, level of organization, influence on and exposure to markets, and power/influence on policy. Large differences also exist within local groups in terms of needs, resource access, interests and power relations. Therefore, great caution must be exercised when classifying a group of people as a 'community' or as a uniform entity and in defining community forestry [8]. Moreover, local groups are not living in isolation; they form part of dynamic forest landscapes, where competing claims and conflicts between different actors is usually the rule rather than the exception. 


\section{Box 1. Indigenous groups, ribereños, extractivistas and colonists}

The Amazon lowlands exemplify the large diversity of peoples living in and around the forests and the different roles forests play in their livelihoods. It is home to such different local stakeholder groups as indigenous peoples, ribereños, extractivistas and colonists/settlers. These groups differ greatly from each other and relate to forests in different ways.

Indigenous peoples. The Brazilian Amazon is home to more than 400 indigenous groups, comprising a large number of distinct ethnic groups. Normally, they live together in small communities in remote tropical rainforest in indigenous reserves, protected areas and/or extractive reserves. They have a strong relationship with the forest (culturally, spiritually and economically), which sustains a large part of their livelihood. Their extractive activities generally have very limited effects on the forest. In the Amazon Basin, especially in Colombia, large areas of forests have been set aside for this traditional way of living. Contact with the outside world used to be rare, but increasingly timber extraction activities, infrastructure or colonization and deforestation schemes are intruding on community areas, affecting the quality of communities' lives and forests. Their inclusion in the wider economic system means their activities are becoming much more related to the outside world, although still organized on a community basis. The financing of forest-related activities depends largely on the market and on mediation by middlemen and timber (and other product) buyers.

Ribereños. In many tropical forest areas, people live along rivers, especially Negro communities in Colombia (Choco), and varzeas and quilombolo communities in Brazil. Such communities usually own a short stretch along the river and all the land behind it. They cultivate the river areas for rice, cassava and plantain throughout the year, and use the hinterland forests to supplement their livelihoods during certain periods. This way of living often goes back generations. Some small farmers (colonos or asentados in Brazil) adopted the same way of living. Ribereños do not form real communities but do express some communalities and some community organization. Put simply, they have created units of 'agricultura familiar', where forests form part of their living. The dependency on forest resources varies with the type of forest (primary, secondary, inundated palm stands), its condition (conserved, changed or degraded) and the legal status of the area (reserva legal, extractive reserve, conservation area). Timber activity is seasonal and extractive activities have limited effects on forests; harvesting intensity is low and only a few species are used. The communities sell the timber at the riverbank to whichever middleman or transporter is passing by, without regulation or control [9]. Income from these activities is particularly important during seasonal shortfalls in food and cash crop income and in periods of drought or other emergencies.

Extractivistas. Various forest-dwelling people's livelihoods depend almost entirely on the small-scale extraction of forest products, timber or non-timber (Brazil nuts, natural rubber, chicle). Extraction is regulated and organized to various degrees, either formal or informal, but usually in a combination of formal and informal. For example, in Brazil asentamientos de extractivistas have permits to live in extractive reserves. Motosierrists (in Bolivia cuartoneros, productores informales or piratas [10] make their living from small-scale lumbering, using chainsaws, axes and machetes. Chainsaw milling has emerged in Guyana as a significant component of the timber industry [11], although it exists in the other countries also. In many countries, these types of small forest-based, highly informal enterprise activity account for a large part of the total harvest from forests. Moreover, they provide income and livelihoods for large numbers of people within and outside forested areas, and influence local and national timber markets. However, little is known about how extractivistas function, including how they are financed and organized. Financing for short-term working capital and long-term lending for chainsaws is largely provided by the informal sector, in part due to inaccessibility of the formal system. For non-timber products, product buyers and middlemen have set up specific financing schemes that are characterized by high interest rates and power dependencies.

Colonists/settlers. From the 1960 s to the 1980 s, public policies in several countries supported the development of large- and small-scale colonization and infrastructural schemes, especially via reduced taxation, subsidies and technical assistance. Since the 1990s, market forces also have led to large-scale deforestation for agriculture purposes, especially in Brazil and Bolivia. Spontaneous colonization, driven by poverty and landlessness, has usually followed or preceded these developments. Cambas in Bolivia, caboclos/ribereños in Brazil, and colonos in Peru, Nicaragua, Ecuador and Colombia have typically come from outside the forest (mostly from the Andean areas in South America). They slash and burn forests, and making a living by planting corn, plantain or other short rotation agricultural crops. Colonists normally do not have a tradition of living in and from the forests. 
This diversity in situations, conditions, interests and objectives, between and within the different groups in relation to forests, also leads to diversity in the flow of costs and income, solvency and the need for liquidity. It also translates into different needs and abilities to access and effectively use external financing. As a result, any given policy or approach will likely have different impacts depending on the specific realities of the beneficiary population (see also [12]).

Specific investment financing and payment mechanisms need to be suited to each situation, also considering the business and investment climate in which they are implemented [8]. Attending to this diversity requires careful participatory diagnostics and flexibility in mechanism design.

\subsection{Financing Forestry with Livelihood Strategies in Mind}

Most rural households rely on diversified production and income-earning strategies where forest-based activities are usually only part of their household enterprise. Forest- and tree-based activities are complemented by agricultural and animal-raising activities and labour income. Forests often function as 'safety nets' in times of crop failure or other emergencies.

It is important to know the specific features, values and functions of forests within this complex livelihood strategy. Forests will be maintained and respected only if the proposed forest-based solutions enhance people's livelihoods. However, experience shows that the financing (e.g., through credit schemes) of small-scale forest activities is too often focused on timber alone without considering the wider context. In practice, different activities could be used for loan repayment in the short term, even when the loan itself is for activities that will generate a positive cash flow only after several years. The Fondo Ganadero of Paraguay, for example, recently created a credit line that allows households involved in cattle raising to get credit for planting activities (see Box 2). In this example, animal husbandry may yield lower rates of return than fast-growing plantations, but it allows farmers to make annual repayments on their loans until the first commercial harvest. Some micro-finance institutions are also using this broader approach to forest financing [13].

\section{Box 2. Bridging the communication gap: The Paraguay experience}

The experience of FAO and the NFP Facility in Paraguay illustrates the synergies that can be realized when the forestry and financial sectors work together. In early 2009, a national workshop on forest financing was held in Paraguay. Co-organized by 11 organizations, the workshop was attended by more than 100 representatives from the public and private sectors, including both the forestry industry and the financial sector. The capacity-building process was initiated against a backdrop of challenging issues (Paraguay has one of the highest deforestation rates in Latin America and donors and development agencies consistently describe its institutional weakness as very problematic) but also promising opportunities, including a new institutional leadership (INFONA, the National Forest Institute, was created in 2008) and a supportive private sector. Other strengths include very favorable tree growth conditions and a dynamic market for forest products, including for bioenergy. Paraguay had also been selected as a pilot country by both the Forest Carbon Partnership Facility and UN-REDD and had received valuable support from various donors to improve its investment climate, most recently by the IADB and the Spanish Government.

The essence of FAO/NFP Facility support has been to facilitate mutual learning between the two sectors, for example through the creation of multidisciplinary working groups and field trips where representatives of the financial sector (e.g., bankers, managers of pension funds, etc.) could observe interesting cases of sustainable forestry (plantations and natural forest management). 


\section{Box 2. Cont.}

Achievements. This work of facilitation has produced a number of initial results. Fondo Ganadero, a bank that supports cattle ranching, has created a new credit line (initially worth US\$1 million) for tree planting on pastureland and pasture improvements. The creation of the line is partly thanks to the fund staff's exposure to interesting cases of plantations intercropped with pastureland and agriculture. The Agencia Financiera de Desarrollo (AFD), a public development bank, is developing a US\$2 million credit line (PROFLORA) for planting activities. The Central Bank is modifying Article 42 of Resolution 6 regulating Law $921 / 96$ on fiduciary transactions, removing the obligation for fiduciary agencies to create a guarantee deposit of 10 per cent for investment trusts. It is expected that the removal of this obligation will open to door to sizeable forestry investments by several private pension funds in Paraguay through a trust mechanism.

Lessons learned. The Paraguay experience with forest financing offers several aspects for consideration.

(1) As mentioned by Savenije et al. [6], the issue of forest financing is not merely about money. Money is available, especially for financially attractive forestry activities. However, financing for the sector is limited by institutional weakness and isolation (communication).

(2) It is more complex and expensive to reach out to small producers than to large landowners. Involving small producers requires improving their organization, investing in capacity building, improving governance, resolving tenure issues (e.g., separating land from tree ownership) and invest in awareness raising. It remains an open question whether small producers will be better served through targeted programs or through an integrated approach that seeks to link them to a healthy forestry sector that also includes large producers, manufacturers and traders. From our limited experience in the country, we posit that it can be strategic to work with progressive and entrepreneurial producers as this has enabled:

- increased visibility of the whole sector in other sectors (financial, agriculture and animal husbandry, economy);

- powerful demonstrations of the potential of the forestry sector, getting other farmers and cattle ranchers interested in reforestation (thus strengthening cross-sectoral linkages);

- job creation (it is estimated that 1 job was created for each 10 ha of planted forests);

- identification of opportunities to create links between large and small producers through private-private partnerships (e.g., outgrower schemes) (Where institutions and extension services are weak, such partnerships offer the opportunity for small producers to have reduced market risk and increased access to markets, financing, seedlings, know-how and technical assistance. However, for these opportunities to be fully realized, tenure/use rights issues need to be resolved. Increased visibility of the sector might nurture the political will to address this fully.); and

- development of market channels that will benefit the whole sector.

(3) In countries like Paraguay (favorable climate and geographic conditions), sustainable management of natural forests faces a number of problems and often is not competitive with alternative land uses, including plantation forestry. For example, in central Paraguay, plantations with exotic species are estimated to yield annual returns in excess of US $\$ 700 /$ ha/year. Certified natural forest management operations yield annual returns of less than US $\$ 50 /$ ha/year, even when factoring in the value added of secondary and tertiary processing. As long as other forest products and services (e.g., water, biodiversity, soil protection, climate mitigation, sites for recreation/tourism, etc.) are generated without benefits for forest users, economic incentives will work against natural forest management.

Forest and financing stakeholders have identified additional opportunities to further strengthen cross-sectoral collaboration through: (1) institutional strengthening (e.g., by establishing within INFONA a focal point for the financial sector); (2) a capacity-building program on business and finance for institutions and other stakeholders; (3) a knowledge-dissemination program on emerging financing opportunities and requirements; (4) development of opportunities for privateprivate partnerships between small and large producers; and (5) the implementation of legal provisions that deal with forest financing, including a public incentive scheme. 


\subsection{Diversity of Financing Instruments and Access}

Small-scale forestry depends on a range of financing instruments. They vary in origin (e.g., funding can come from international donors, public budgets or private resources), objectives (financing can be an instrument to create monetary value added or social or conservation benefits), distribution mechanisms and intended beneficiaries [14]. Whilst there is some documentation on the extent and effectiveness of donor and public funding (see, for example, [15-17]), less is known about private financing, whether formal or informal [18]. Box 3 offers an overview of the financing alternatives commonly encountered in Latin America.

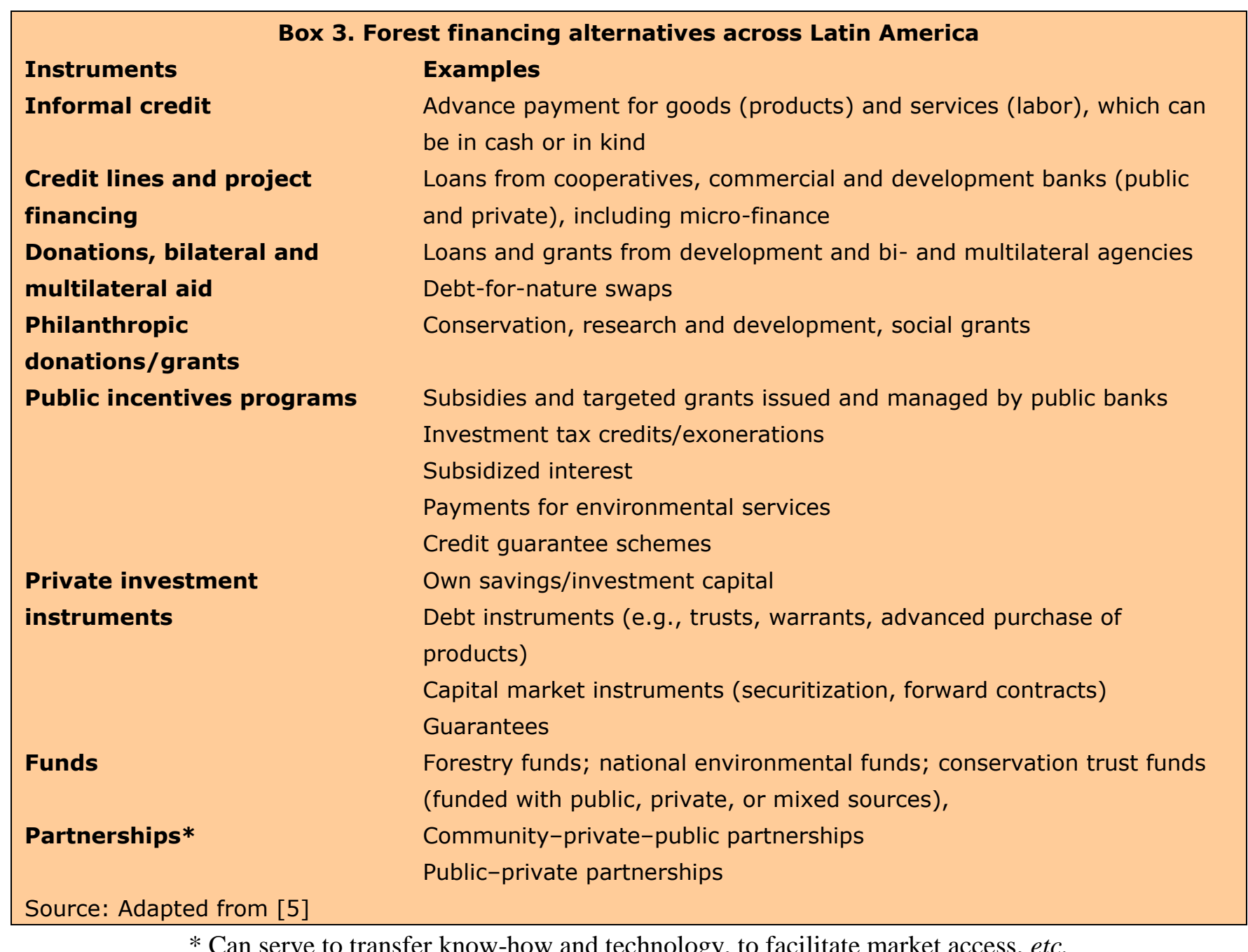

Many small producers have limited access to formal financing, for several reasons including that: (1) Forests are often not acceptable collateral for a loan (exceptions include Colombia and Uruguay); (2) land cannot be used as collateral without clear land tenure; (3) lending policies favor low-risk and short-term loans; and (4) interest rates are often higher than the rate of forest value growth when timber is the only marketed output.

For these reasons, many small producers rely on informal financing even when lending conditions are unfavorable (e.g., very high interest rates). A huge and largely undocumented amount of forestry activities takes place outside 'formal' financing schemes - a situation that is more common where 
access to formal financing for small-scale forestry is limited. Indeed, in rural and remote regions, strengthening and expanding operations of existing informal value chains may work better than trying to attract urban financial institutions to rural areas [13]. Informal financing may be how a small enterprise can gain its footing. However, information on informal financing of forest activities is limited (see Box 4 for some examples).

\section{Box 4. Examples of informal financing}

For motoserristas and collectors of non-timber forest products, studies indicate the existence of a large informal chain of financing by middlemen, sawmills, brokers and transport firms, which maintains the production chain. The system of habilito in Peru and Bolivia exemplifies its workings.

The habilito system in the Bolivian Amazon [19] can be defined as a set of rules (written or spoken) governing an advance cash payment or goods (mainly foodstuffs) for labor service to collect Brazil nuts, rubber or timber. Typically, the advanced cash and goods received are recorded as a debt against the collector, who repays the total owed with the product recollected. However, the system finances not only the collection phase but also the subsequent phases of processing and transport [19].

Habilitación in Peru is an important informal financial service that helps to keep the timber industry running. The timber industry generates about $€ 77$ million per year, a good part of which is financed by habilitación. Despite the acute limitations facing producers in remote areas and the lack of public administration and banking services, working capital for forest operators continues to flow. Habilitación involves an extensive network of economic agents (habilitadores and patrones) willing to provide lending operations in the most remote areas along the Amazon River Basin despite unfavorable conditions such as lack of equipment, administrative skills and management plans [20]. The habilitador, also known as maderero, is a merchant who, through patrones, distributes cash at very high interest rates (often up to 100 per cent), food staples and equipment in order to supply specific species of timber.

Source: [20].

Notwithstanding the widespread use of informal financing schemes, van Dijk and Savenije [1] consider there to be untapped potential to link forestry to domestic private capital through formal financing instruments, especially for productive activities. Important potential for additional and new sources for investment exists through the creation of capital market instruments (institutional capital, private capital, and business capital), the development of mechanisms for PES (local, national and global), the broader use of risk mitigation instruments and the bundling and/or packaging of multiple instruments.

Tapping into domestic private capital requires bridging the significant communication gap that exists between small forest producers and formal financing institutions (see, for example, Box 2). Access to formal financing instruments also requires that forest operators organize themselves and their operations in business plans that are properly structured and financially solid [21].

\section{The Importance of an Enabling Environment}

Van Dijk and Savenije [1] emphasize that it is crucial to have an enabling environment for the provision of financing on a national, regional or local level. Indeed, other agencies have supported efforts to improve investments in SFM by improving the environment for forestry investments. An example is the Forest Investment Attractiveness Index, which uses a methodology developed by the Inter-American Development Bank for the purpose of measuring the business climate for investments in sustainable forestry business. The index, through a quantification of policy, institutional, economic and resource base indicators, aims to instigate a process to improve the business climate for forestry 
investments [22]. In the following paragraphs, we briefly discuss selected elements of this enabling environment, particularly focusing on governance and institutions, meaningful participation, and tenure. Additional elements of an enabling environment, like adequate policies and legislation are discussed elsewhere $[1,5,22]$.

\subsection{Governance and Institutions}

Our experience in Latin America has led us to conclude that lack or limitation of financing options is less about money availability than about access. In turn, our experience supports the view that the challenge of increasing financing goes hand in hand with the challenge of increasing the attractiveness of SFM in general and of forest institutions (public and private) in particular [7].

Even though no rigorous testing has been applied to the following propositions, anecdotal evidence suggests that the success of public or private forest institutions in attracting the attention of the financial sector and mobilizing new and additional funding for SFM can be linked to their ability to:

1. maintain or improve their level of technical competency and credibility vis-à-vis the ministry/ministries in charge of finance;

2. acquire knowledge about financing language, instruments and processes;

3. build alliances with other sectors, in particular the financial sector;

4. monitor activities and their impacts, enabling assessments of cost effectiveness;

5. proactively seek to take advantage of emerging markets and instruments for forest goods and services; and

6. balance institutional capacity (human, financial and technical) with institutional mandates.

The importance of competence, credibility, accountability, innovation and participation can perhaps be illustrated with public programs, such as PINFOR, or 'best practices' that have emerged from the review of conservation funds. The PINFOR program (see Box 5) of Guatemala is an example of a national incentives program that owes its success to the fact that it is run by a national forest agency (INAB) that enjoys broad public credibility. INAB is governed by a Board of Directors that includes representatives from government ministries (agriculture and finance), the national association of municipalities, the private sector, NGOs and universities. The Board directly selects its chair, who is not a political appointee. This means, for example, that in its 13 years of institutional life, there have been far fewer chairs of INAB than ministers of agriculture.

Funds too have had most success (both in terms of impact and in being replenished) when careful attention has been given to the design of effective governance structures. For example, an early review of conservation trust funds [24] concluded that 'to succeed, trust funds need the governance structures, staff, and technical support to allow them proactively to influence their environment, monitor their results and learn from experience, maintain credible and transparent procedures, and support participatory approaches to conservation and sustainable development'. A more recent review reached similar conclusions [16]. The latter concluded that funds require government support even when they are not controlled by government and that independence from authorities is often associated with greater transparency and may assist in raising finance from international agencies and the domestic private sector. 


\section{Box 5. Forest incentives programmes in Guatemala: PINFOR and PINPEP}

PINFOR (Programa de Incentivos Forestales) is an incentive programme started by the Government of Guatemala in 1997. It is financed using one per cent of the state operating expenses. Between 1998 and 2009 , it provided about US\$134 million to the forestry sector. Annual disbursements grew from US\$5.6 million in 2000 to US\$16.9 million in 2006. In the past two years, the effects of the global economic crisis on Guatemala caused the amounts allocated to the program to fall to US\$9.7 million in 2008 and US\$5.5 million in 2009 [23]. To date, the program has contributed to the establishment of about 100000 ha of plantations. Municipalities, communities, landowners and other organizations can apply for incentives to fund reforestation, promote natural regeneration and improve natural forest management. Full ownership of the land (registration in the Registro de Propiedad Inmueble) is required to access the program. PINFOR supports the national goal of integrating and concentrating wood production and processing in the country whilst also meeting conservation objectives. The Ministry of Public Finance makes payments directly to beneficiaries following the receipt and approval of Certificados de Incentivos Forestales by INAB, the national forest agency. Funds are audited by the Contraloria General de Cuentas. The beneficiaries carry out planning, control on spending and monitoring, and INAB certifies plantation success and fire protection activities. INAB receives nine per cent of the programme funds as overhead for its support activities. Preliminary analyses suggest that the program has been quite successful at stimulating private investments in forestry and that each dollar disbursed will have an estimated impact in the national economy of about $\$ 6$ [23].

Amongst the main challenges of the program are that: (1) since its inception, the program has consistently received less than the amount established by law; (2) approximately 20 per cent of requests cannot be fulfilled for lack of funds; (3) program design does not allow for contributions from other sources; and (4) many small-scale forest users are excluded from the program because of the requirement to prove land ownership. To overcome the first three challenges, INAB may consider redesigning the program as a fund (e.g., FONAFIFO) that can receive private contributions and donations from bilateral and multilateral agencies.

To overcome the last challenge, the Government of Guatemala, with support from the Netherlands, has created an incentive program for smallholders (Programa de Incentivos para Pequeños Poseedores or PINPEP). The program is managed by a Board of Directors comprising representatives from the Asociación Nacional de Municipalidades, the Dutch Embassy, INAB and the Red de Comunidades Organizadas. The Board is chaired by INAB and makes decisions by majority. The Board is responsible for PINPEP'S policy and strategy, evaluation, monitoring and definition of technical and administrative measures. The investments are audited by the Contraloria General de Cuentas. PINPEP benefits mainly communities and organized groups, but small and medium producers can also use the funds. The program also gives incentives to officially recognized protected areas. The main conditions of the incentive are that individual lots should not exceed 15 ha (communities can have more) and that beneficiaries live on forest vocation land. The funds supplied are managed entirely by the beneficiaries, be they communal or individual. Beneficiaries have to present annual reports and activity plans. INAB monitors employment generation, planted areas and management (including fire control) activities realized. Congress will evaluate in October 2010 a proposal for the replenishment of PINPEP with public funding in amounts ranging from 0.25 per cent and 0.5 per cent of the state operating budget. Comprehensive information about PINFOR and PINPEP is available at http://www.inab.gob.gt.

Source: Courtesy of INAB and Programa Forestal Nacional de Guatemala.

\subsection{Meaningful Participation}

Multi-actor participation and transparency also improve monitoring and impact. Facilitating these requires institutional arrangements that ensure local meaningful participation, not only in the design of site-based projects and programs but also to achieve local engagement in political decision making at multiple scales. An example is the recent creation of the National Alliance of Community Forest Organizations of Guatemala (see Box 6) and the rapidly growing interest for community and indigenous groups to speak with a common voice on matters related to financing and investments (see, for example, the Forest Dialogue workshop series on Investing in Locally Controlled Forests http://environment.yale.edu/tfd/dialogues/locally-controlled-forestry/). 


\section{Box 6. An integrated approach to forest financing in Guatemala}

Guatemala provides a good example of a country-driven effort to improve financing for small-scale forestry. During a national workshop on forest financing held in November 2007, participants recognized that greater understanding and collaboration between the forestry and financial sectors would have the potential to benefit both sectors and generate positive impacts in economic, social, and environmental terms. Workshop participants also recognized that improving financing for SFM by small users, communities and indigenous groups required an integrated approach. The workshop set in motion a set of initiatives, jointly supported by INAB, FAO, IUCN, IIED and the World Bank (known as the Growing Forest Partnerships), in support of four key dimensions.

Governance. Small forest users, communities and indigenous groups have recognized that, as a group, they were disorganized, uninformed and poorly equipped to operate in a market for products and services. Their lack of coordination and a common vision also hindered their ability to influence forest policy decisions and the development of financing solutions appropriate to their needs. To address these weaknesses, the National Alliance of Community Forest Organizations of Guatemala (Alianza Nacional de Organizaciones Forestales Comunitarias de Guatemala) was created in 2009. It provides a forum for 11 second-level organizations and 400 grassroots organizations in Guatemala to find a common voice and influence decisions on the design of forest public funding programmes (such as PINFOR, PINPEP, PPAD) and formulation of forest policy (a review of the country's forest policy is underway), and to engage with REDD+ readiness initiatives. It also provides them with an opportunity to identify key priorities for action and capacity-building needs with a broad basis of consensus. This level of coordination amongst indigenous groups and community forest organizations is unprecedented in Guatemala. Interestingly, though, for all its efforts, the Alliance only represents at best 50 per cent of the country's forest-dependent people. A network of indigenous authorities (Red de Autoridades Indigena) has so far been reluctant to join the Alliance and many households and small communities are so poor and isolated that they are not within the reach even of local organizations.

Financing mechanisms. Working together, forest and financing representatives have identified 4 possible financing instruments with potential for development in the short to medium term: (1) micro-credit; (2) 'factoring'; (3) repurchase agreements; and (4) securitization of forest-based cash flows. An assessment with financial institutions regarding the feasibility and attractiveness of the above instruments pointed to factoring and micro-credit as instruments with potential for piloting in the short term. Repurchase agreements and securitization are also attractive instruments but require greater levels of organization and capacity amongst producers. Factoring allows operators to raise cash to finance operating capital (e.g., to rent equipment) or labor using contracts for future sales as collateral. Besides these private financing instruments, Guatemalan stakeholders are also evaluating public financing options such as the reprogramming of PINFOR and the public financing of PINPEP (see Box 5).

Institutions. One of the critical bottlenecks in the development of financing instruments in Guatemala has been the availability of the economic-financial information needed to prepare 'bankable' projects and properly estimate the value of forest assets and future forest earnings. Another constraint has been the lack of known methodologies in Guatemala for rigorously assessing forestry investment risks and the availability of instruments to manage them. Furthermore, a number of policy and institutional constraints limit access to financing for forest stakeholders. To address these issues, a National Forest Financing Strategy was formulated and approved by the Board of Directors of INAB, the Guatemalan forestry authority. Within INAB, a small team was appointed to establish a Forest Finance Intelligence Unit (Unidad de Inteligencia Financiera Forestal or UIFF) to follow up and implement finance instruments identified to benefit smallholders and forest communities. The unit is providing forest finance information and capacity-building opportunities for foresters and finance professionals and facilitating the development of pre-investment initiatives (business cases). The country is also evaluating options to operationalize a forest credit guarantee fund (Fondo de Garantía Crediticia) that was created with the forestry law and capitalized with national funds but has not been used because of the lack of regulations. INAB has found itself in a financially vulnerable position as it relies extensively on public financing for its operations; it is currently evaluating options to diversify its financial base.

Market chains and enterprise development. Ongoing initiatives include: characterization of producer forest value chains with definition of financial profiles for small-, medium- and large-scale producers; and technical support of small-scale enterprises in terms of market and enterprise development.

Wiersum [25] notes that, regarding international policy concerns for the rights of indigenous peoples, these groups are increasingly represented as a recognized stakeholder at the policy tables, including REDD+ discussions. However, colonos and other forest fringe people usually cannot yet refer to similar international agreements (such as the Declaration on the Rights of Indigenous Peoples) 
or are not organized in the same way. Additional policy measures, including empowerment and capacity-building activities, will be needed to develop effective institutional capability amongst these forest-dependent people to ensure their active engagement.

\subsection{Tenure}

The importance of secure forest tenure as a precondition for the effective local implementation of rural development initiatives (including activities to be supported through REDD+ financing) has received considerable emphasis. For example, a comprehensive assessment of national policy changes needed to implement REDD+ at the country level identifies land tenure as one of the key areas requiring reform [26]. However, how strong is the relationship between improved tenure security and the incentives to reduce deforestation and invest in SFM? Larson et al. [27] and Gilmour and Fisher [28] conclude that tenure alone is a necessary, but often insufficient, condition to promote changes in land use in the absence of other incentives, investments in capacity and other conditions.

In a review of community forest management operations in seven regions of four Latin American countries, Larson et al. [27] conclude that improvements in forest tenure have clearly enhanced opportunities for participation in formal timber markets, enabled investments (especially by donors), strengthened communities' positions for negotiating the terms of sale of products and led to increases in profits. However, they also point out that the degree to which communities can benefit from clarified tenure arrangements heavily depends on a variety of factors such as the conditions of the natural capital granted to communities. Where forests are rich and located in areas with access to markets, the benefits from improved tenure have been more significant than where forests are poor or degraded (e.g., due to previous logging activities). Finally, even with improved rights, communities may fail to engage in timber markets beyond the sale of standing trees and have limited capacity to strengthen their negotiation positions, because they depend on service providers that are allied to buyers in local markets.

Some countries (e.g., Paraguay) are attempting to minimize the adverse effects on forestry investments caused by insecure tenure by passing legislation that separates ownership of the land from ownership of the trees [29]. This may allow trees to be used as collateral for loans, independently of land ownership, as in Colombia [30]. It remains to be seen whether these legislative attempts will translate to increased forestry investments.

Some countries are also revising their forestry laws or constitutions (e.g., Ecuador) specifically to regulate PES-like mechanisms [31]. Anticipating REDD+ financing, efforts aimed at resolving tenure uncertainties are high on the agenda of many developing countries. For example, in Mexico, a proposal to include a clause on carbon credit trading that reflects an agreed-upon protocol is being studied. Given that up to 75 per cent of forest vocation land (tierras de vocación forestal) in Mexico is communally held (ejidos) or belongs to municipalities or indigenous communities, such protocols ensure that unresolved questions on tenure will not compromise the sale and trade of Mexican forest-based carbon credits [32]. Another option considered, consists of the development of private contract schemes regulating rights and responsibilities of the parties related to carbon credits, based on simplified legal requirements [32]. 


\section{Communication, Partnerships and Outreach}

The development and implementation of innovative financing mechanisms are in many ways akin to the adoption of new technologies, in that they are associated with significant upfront costs and capacity barriers for many stakeholders. Our experience clearly reveals a large gap between experts in the forestry and financial sectors, in terms of knowledge, expertise and culture. This hinders mutual understanding, exchange and cooperation between the two disciplines. Most forestry experts lack basic knowledge on financing and the capacity to 'translate' finance knowledge to their own work. Similarly, many finance experts lack the necessary background in forest management to assess it financially or to design tailor-made financing instruments.

Our collaborative experience in supporting the development of financing strategies and instruments suggests that stronger interaction, cooperation and knowledge sharing with other sectors that are important to forests (e.g., finance, agriculture, energy and water) can provide significant win-win opportunities for all sectors involved (see Box 2). Likewise, experience demonstrates that there is much to gain in promoting new partnerships, for example between large and small forest enterprises, public and private entities, and national and international companies.

Building these partnerships requires forest stakeholders to reach outside their forestry circles more than they have in the past. This is a challenge because the attitudes and skills needed to effectively identify the most promising counterparts and communicate the opportunities that forestry presents are often weak. 'Soft' investments (e.g., by public institutions, donors, social or conservation investors) may be needed for technical capacity building and for organizational and institutional development [14]. The forestry sector as a whole must adopt a more active, strategic and political position in public debate and must find ways to contribute to current political and intersectoral agendas, indicating clearly what it has to offer [33].

\section{The Need for an Integrated Approach}

In their report on financing mechanisms in Latin America, van Dijk and Savenije [1] emphasize that forest financing should be examined in an integrated way, taking into account 4 main elements and their interrelations:

1. sustainable forest management (SFM) in its potential to contribute to rural development, poverty alleviation, and sustainability (careful attention should be given to the diversity amongst forest actors, forest types, management objectives and conditions, as such diversity leads to differentiated needs and possibility for financing);

2. investment mechanisms: the whole set of sources, instruments and operators for financing, promotion and risk mitigation of investment in SFM;

3. payment mechanisms for forest services and goods: the whole set of sources, instruments and operators to establish adequate payments to forest managers; and

4. the enabling environment necessary for effective functioning of financing mechanisms.

They conclude that the prospects for supporting SFM improve where financing takes place within a supportive policy and institutional environment, including security of land tenure; where a forest strategy is aligned with long-term national priorities and commitments; where forestry information 
(e.g., on markets, productivity, legislation, institutional arrangements) is available and accessible; where legislation encourages the development and use of market mechanisms, including PES; and where synergistic incentive packages that combine financing with favorable investment, credit and trade policies are used (see also [5]). The opportunity to bundle multiple financing sources (e.g., as they relate to multiple forest goods and services) also merits greater attention.

The Guatemala experience in developing financing options for small-scale forestry, provides an interesting illustration of an approach that complements the development of investment mechanisms with market and enterprise development and with the strengthening of governance and institutional structures (see Box 6).

The case highlights the importance of addressing the issue of forest finance together with a number of key institutional weaknesses that currently limit constructive communication between the forestry and financial sectors: Limited knowledge of financing language, instruments and processes; isolation from other sectors and from other key stakeholders within the sector; a legacy of dependence on public resources, both domestic and international, with a focus on limited instruments; and inadequate attention to efforts to improve the climate for investment and market development.

\section{Key Considerations}

From the experience of FAO, the NFP Facility and their partners, we have identified several aspects that should be considered by donors and development agencies when supporting the development of forest financing instruments and strategies and which may be relevant to REDD+ financing at the national level. The main considerations are listed here.

1. Integrate REDD+ financing within broader national strategies for forest financing. The authoritative publication Realizing REDD+ [26] makes a compelling case that effective implementation of REDD+ requires broad reforms and a comprehensive strategy:

Agricultural policies can limit the demand for new agricultural land. Energy policies can limit the pressure on forest degradation caused by wood-fuel harvesting, while reduced impact logging (RIL) practices can limit the harmful impacts of timber extraction. Setting up protected areas (PAs) has proved effective in conserving forest, and — although being far from perfect - support for PAs should be considered as part of any comprehensive national REDD+ strategy.

Indeed, a national REDD+ strategy is a requirement to fully benefit from mechanisms such as the Forest Carbon Partnership Facility and the UN-REDD program. Based on the lessons learned on the effectiveness of other financing instruments (see previous section and the example of Guatemala in Box 6), we add here that policies and instruments will be even more effective if synergies are found with other financing options and with activities aimed at organizing vulnerable forest stakeholders and at strengthening other markets and their entrepreneurial capacities. Such synergies can be explored and operationalized through national forest financing strategies. Strategies describe a country's common vision for the future of forests and people, outline priorities and assess the requirements to achieve that vision. Many such strategies form an integral part of national forest programs. Experiences from Latin America suggest that financing strategies can support this vision when they: 
1. are based on negotiation and agreement amongst all major stakeholders in countries, including representatives of the financial sector;

2. promote diversification in and synergies across financing sources and mechanisms, responding to the various forest management conditions and needs of different forest users;

3. ensure that a supportive institutional, legal and socio-economic environment for investment and market development is in place; and

4. include the multiple benefits of forests as management objectives in appropriate locations and circumstances [5].

2. Ignore local diversity at your peril. As discussed in Section 2.1, it will remain a challenge to devise financing mechanisms that can respond to the diversity and dynamics of local realities and forest users. We found that attributes such as pragmatism, flexibility and adaptability are necessary. Mechanisms can be enhanced by respecting the pace at which things can change and respecting stakeholders' internal ability to adjust and change. In our view, a key challenge is not only to identify what measures are needed to make countries 'REDD ready', but also to design REDD+ finance mechanisms that are 'community ready', i.e., that are client-driven, respectful of local diversity and specificities, and that embrace the view that local communities are the driving forces of their own social and economic development and best placed to consider their own realities, needs, aspirations and dynamics.

3. Consider existing livelihood strategies as the starting point. One concrete way to adapt financing to local realities is to design and implement financing schemes with a view that goes beyond forest financing needs and addresses the livelihood strategies of different groups. For a large portion of forest-dependent people, forests are not the most important source of livelihood. Credit schemes that permit repayments based on income from agriculture and animal husbandry can improve forest management and household incomes. Compensation schemes, that respond to community needs and that look beyond forests, have proven to be promising, practical and sustainable (e.g., [34]).

4. Build on existing structures but be mindful of their strengths and weaknesses. The increased opportunities for SFM financing mentioned in the previous sections are taking the form of a proliferation of new funds. At the country level, such proliferation raises the question as to whether the consultative processes that these funds call for, should use existing platforms or build new ones. Our support to the development of National Forest Financing Strategies has used national forest programs as a platform for stakeholder engagement. In using this platform, a common challenge we have encountered has been institutional weakness and isolation, which often manifests itself through limited convening power or a stifling competition between environmental and forestry agencies. Poor communication and cooperation are negatively affecting the development of REDD+ strategies that are credible and have a broad support base. An open question is thus, whether in order to improve governance, development agencies should rely on traditional forest institutions and established processes such as national forest programs or on alternative participatory governance structures. The answer will partly depend on these agencies' ability to meet this challenge and fill a gap in their capacity for partnership and outreach.

5. Be strategic. When resources are limited, the discourse on supporting better governance, financing mechanisms design and implementation, public and private institutions, improved 
information management and market and enterprise development, risks becoming a wish list with limited follow-through. In these cases, we have found it essential to resort to 'best practices' such as investments in stakeholders' capacity for partnership and outreach. In our experience, we have consistently found that cross-sectoral partnerships are better achieved if facilitated by agencies or individuals with undisputed credentials and strong connections outside the forestry sector. We have also found it important to be 'strategic'. For example, whether communities are better served through targeted interventions (e.g., direct support to the Alliance in Guatemala) or through broader support to the sector (e.g., by facilitating linkages between small producers and medium-sized and large producers, as in Paraguay) will depend on country circumstances and the relative strengths and weaknesses of the various forest stakeholders.

6. Promote innovation, knowledge sharing and information exchange. Over and over again, we have been surprised by the limited knowledge the forestry and financial sectors have of each other. When this veil of mutual ignorance is lifted, we consistently find that (1) significant domestic financial resources are available to the forestry sector and that (2) financial institutions can be formidable allies in devising innovative solutions to the problems of the forest-dependent poor. Forest stakeholders thus need to reach beyond their traditional networks and invest in better communication and collaboration with other sectors, public and private entities and civil society.

\section{Acknowledgments}

This paper was presented at the "Workshop on Forest Governance and REDD+ in Latin America and the Caribbean: A CLI in Support of UNFF", held 31 August-3 September 2010 in Oaxaca, Mexico. We are grateful to Jerker Thunberg, Sophie Grouwels, Jhony Zapata, Rao Matta, Elena Petkova, Pablo Pacheco, workshop participants, and two anonymous reviewers for their valuable comments and suggestions. Any remaining error is our own.

\section{Disclaimer}

The views expressed in this publication are those of the author(s) and do not necessarily reflect the views of the Food and Agriculture Organization of the United Nations.

\section{References and Notes}

1. van Dijk, K.; Savenije, H. Towards National Financing Strategies for Sustainable Forest Management in Latin America: Overview of the Present Situation and the Experience in Selected Countries; Forestry Policy and Institutions, Working Paper 21; FAO: Rome, Italy, 2009. http://www.tropenbos.org and http://www.fao.org/forestry/finance/en/ (accessed on 5 July 2010).

2. Chipeta, M.E.; Joshi M. Financing sustainable forest management. Report of the International Workshop of Experts. 22-25 January 2001, Oslo, Norway; CIFOR: Bogor, Indonesia, 2001.

3. Van Bodegom, A.J.; Savenije, H.; Wit, M.; Boot, R.; Saile, P. Forests and climate change: an overview. In Forests and Climate Change: Adaptation and Mitigation; van Bodegom, A.J., Savenije, H., Wit, M., Eds.; Tropenbos International: Wageningen, The Netherlands, 2009. 
4. Bleaney, A.; Peskett, L.; Mwayafu, D.; REDD-plus after Copenhagen: what does it mean on the ground? REDD-net COP15 Briefing, 2010. Available online: http://www.redd-net.org (accessed on 19 July 2010).

5. FAO. Financing Sustainable Forest Management; Forestry Policy Brief; FAO: Rome, Italy, 2009. Available online: http://www.fao.org/forestry/16559-1-0.pdf (accessed on 19 July 2010).

6. Savenije, H.; van Dijk, K.; Boscolo, M.; Zapata Andía, J. Financing strategies in national forest programmes - The broader approach. Background, conceptual framework and lessons from Latin America. Presented at the XIII World Forestry Congress, Buenos Aires, Argentina, 18-23 October 2009.

7. Boscolo, M.; Zapata, J.; van Dijk, K.; Savenije, H. Cultivating leadership, participation and inter-sectoral dialogue through the development of forest financing strategies: emerging lessons. Presented at the XIII World Forestry Congress, Buenos Aires, Argentina, 18-23 October 2009.

8. Manejo forestal comunitario en américa Latina; experiencias, lecciones aprendidas y retos para el futuro; Sabogal, C., de Jong, W., Benno, P.; Bastiaan, L., Eds.; CIFOR: Bogor, Indonesia, 2008.

9. D’Óliveira, M.V.N.; Swaine, M.D.; Burslem, D.F.R.P.; Braz, E.M.; de Araujo, H.J.B. Sustainable forest management for smallholder farmers in the Brazilian Amazon. In Slash-and-Burn Agriculture. The Search for Alternatives; Palm, C.A., Vosti, S.A., Sanchez, P.A., Ericksen, P.J., Eds.; Columbia University Press: New York, NY, USA, 2005.

10. Pacheco, P. Estilos de desarrollo, deforestación y degradación de los bosques en las tierras bajas de Bolivia (Styles of development, deforestation, and forest degradation in the Bolivian lowlands); CIFOR/CEDLA/ TIERRA: La Paz, Bolivia, 1998; p. 389.

11. Kerrett, R.; Wit, M. Chainsaw Milling in Guyana: A synopsis of the Issues. Tropenbos International: Wageningen, The Netherlands, 2009. Available online: http://www.tropenbos.org/ images/Tropenbos/Eu-chainsawmilling/documentation/guyana\%20newsletter.pdf (accessed on 5 July 2010).

12. Martin, R.M. Deforestation, land-use change and REDD. Unasylva 2008, 59, 3-11.

13. Microfinance and Forest-Based Small-Scale Enterprises; FAO Forestry Paper 146; FAO: Rome, Italy, 2005.

14. Elson, D. Investing in locally controlled forestry: reviewing the issues from a financial investment perspective. Background Paper to The Forest Dialogue, London, UK, 24-25 May 2010. http://environment.yale.edu/tfd/uploads/TFD_ILCF_London_Backgrounder_Elson.pdf (accessed on 5 July 2010).

15. Bayon, R.; Deere, C.; Norris, R.; Smith, S. Environmental funds: lessons learned and future prospects. Available online: http://economics.iucn.org (accessed on 19 July 2010) (Issues-20-01). IUCN, 1999.

16. Conservation Finance Alliance (CFA). Rapid review of conservation trust funds. Prepared for the CFA Working Group on Environmental Funds by Barry Spergel and Philippe Taïeb. CFA, 2008. Available online: http://www.fmcn.org/documentos/RapidReviewCTFsMay08Final.pdf (accessed on 5 July 2010). 
17. From Goodwill to Payments for Environmental Services: A Survey Of Financing Options for Sustainable Natural Resource Management in Developing Countries; Gutman, P., Ed.; WWF Macroeconomics for Sustainable Development Program Office: Washington, DC, USA, 2003.

18. Tomaselli, I. Brief Study on Funding and Financing for Forestry and Forest-Based Sector: Report to the United Nations Forum on Forests Secretariat; United Nations: New York, NY, USA, 2006.

19. Bojanic Helbingen, A.J. Balance is Beautiful-Assessing Sustainable Development in the Rainforests of the Bolivian Amazon; PROMAB Publication Series 4; PROMAB: Riberalta, Bolivia, 2001.

20. Maravi, E.; Kometter, R.; Gonzalez, V. Timber extraction in Peru. In Financing Sustainable Forest Management; Holopainen, J., Wit, M., Eds.; ETFRN News no 49; Tropenbos International: Wageningen, The Netherlands, 2008.

21. KIT and IIRR. Value Chain Finance, Beyond Microfinance for Rural Entrepreneurs; Royal Tropical Institute and International Institute for Rural Reconstruction: Nairobi, Kenya, 2010.

22. Kilian, B.; Pratt, L.; Daley, S. The IADB's Forest Investment Attractiveness Index-The results of the index for 2006 and review on the methodology. Presented at the annual meeting of the BALAS Annual Conference, ITESM, Guadalajara, Mexico, 1 April 2009. Available online: http://www.allacademic.com/meta/p301379_index.html (accessed on 5 July 2010).

23. Monterroso, O.; Vargas, R. Análisis del impacto económico de las plantaciones forestales incentivadas por el PINFOR en la cadena productiva forestal y no forestal. INAB/PFN Guatemala/FAO/GFP: Guatemala City, Guatemala, 2010.

24. Experience with Conservation Trust Funds; Evaluation Report \#1-99; Global Environment Facility: Washington, DC, USA, 1999.

25. Wiersum, K.F. 2009 Community forestry between local autonomy and global encapsulation: quo vadis with environmental and climate change payments? Presented at the First Community Forestry International Workshop: Thinking globally - acting locally: community forestry in the international arena, Pokhara, Nepal, 15-18 September 2009.

26. Realising REDD+: national Strategy and Policy Options; Angelsen, A., Brockhaus, M., Kanninen, M., Sills, E., Sunderlin, W.D., Wertz-Kanounnikoff, S., Eds.; CIFOR: Bogor, Indonesia, 2009.

27. Larson, A.M.; Cronkleton, P.; Barry, D.; Pacheco, P. Tenure Rights and Beyond: Community Access to Forest Resources in Latin America; Occasional Paper no. 50; CIFOR: Bogor, Indonesia, 2008.

28. Gilmour D.A.; Fisher, R.J. Forest Tenure, Sustainable Forest Management and Livelihoods: An Approach to Forest Tenure Reform (Draft); FAO: Rome, Italy, 2010..

29. Federación Paraguaya de Madereros (FEPAMA). Se busca agilizar en el Congreso aprobación de Ley de 'Vuelo Forestal'; Boletín No 11 - Viernes, 07 de mayo de 2010. Available online: http://www.fepama.org/boletin/11/nota03.html (accessed on 19 July 2010).

30. Congreso de Colombia. Ley General Forestal 1377 of 8 January 2010. 
31. IUCN (International Union for Conservation of Nature). Compensación por servicios ambientales: cada país construye su propio camino. IUCN, 27 October 2009. Available online: http://www.iucn.org/es/sobre/union/secretaria/oficinas/sudamerica/?4120/pagoporserviciosambien tales (accessed on 20 July 2010).

32. CEMDA (Centro Mexicano de Derecho Ambiental). Tesis privada sobre contratos privados para la compraventa de $\mathrm{CO}_{2}$; CEMDA: Mexico City, Mexico, 2010.

33. Savenije, H.; van Dijk, K. World forestry at a crossroads: going it alone or joining with others? Unasylva 2010, 61, 66-70.

34. Boscolo, M.; Eckelmann, C.; Madrigal, R.; Mendez, B.; Paveri, M.; Zapata, J. Mecanismos operativos compensatorios que vinculan al bosque con el agua en América Central y el Caribe. Presented at the XIII World Forestry Congress, Buenos Aires, Argentina, 18-23 October 2009.

(C) 2010 by FAO; licensee MDPI, Basel, Switzerland. This article is an open access article distributed under the terms and conditions of the Creative Commons Attribution license (http://creativecommons.org/licenses/by/3.0/). 